\title{
Perceived Risk Influence on Brand Made in Ghana Consumer Decision Making towards Non-Perishable Products Category
}

\author{
Abraham Yeboah ${ }^{1}$, Vida Owusu-Prempeh ${ }^{2} \&$ Samuel Adjei $^{3}$ \\ ${ }^{1}$ Department of Marketing, Sunyani Technical University, Sunyani, Ghana \\ Correspondence: Abraham Yeboah, Faculty of Business and Management Studies, Sunyani Technical University, \\ Sunyani, P.O. Box 206, Sunyani, Ghana. E-mail: yeboah.a@stu.edu.gh
}

Received: January 31, 2018

Accepted: March 17, 2018

Online Published: April 18, 2018

doi:10.5539/ijbm.v13n5p137

URL: https://doi.org/10.5539/ijbm.v13n5p137

\begin{abstract}
The main purpose of this research study is to explore perceived risk influence on brand made in Ghana consumer decision making towards non-perishable products category. The study is particularly positioned to advance knowledge in the theories of buyer behaviour pertaining to the purchase consumer decision model (EKB model Engel, Kollet, Blackwell). The key variables investigated include performance risk, financial risk, physical risk, and social risk. A sample of 206 respondents was employed using convenient selection method. A self-completed 5 point Likert structured questionnaire survey was the data collection instrument used. The data collected were computed and analysed by linear regression to determine significant influence of the variables involved in this study. Overall results of the perceived risk variables showed that only performance risk was found significant influence on brand made in Ghana consumer decision making towards non-perishable products category. Among the variables that are rejected with no significant influence on brand made in Ghana decisions includes financial risk, physical risk, and social risk. It is recommended that manufacturers and policy makers develop more pragmatic and practical integrated approach supported by policy document in order to sensitise minds of consumers towards brand made in Ghana.
\end{abstract}

Keywords: perceived risk, brand made in Ghana, consumer decision making and non-perishable product category

\section{Introduction}

A lot of effort towards marketing campaign through traditional and modern media for attitudinal change is being carried out by several stakeholders such as government, marketing and sales practitioners, opinion leaders, as well as business owners to affect consumers in Ghana to select brand made in their home country (Abissath, 2015). The level of marketing campaign being run appears to be a daunting task and yielding no positive results on the part of consumer decision making towards brand made in Ghana. Among non-perishable products made in Ghana range from shoes, sandals (leather / rubber), textile, drugs, electrical gadgets, raw rice, shirts, and so on (Opoku \& Akorli, 2009). Interestingly, these consumers preferably select similar items from another part of the market - products from foreign countries. Though, a number of factors have been attributed to the consumers' reasons not to select made in Ghana brand or products such as quality, source credibility, price, availability, product attractiveness, and more. The buying of foreign brands is on the rise (Abissath, 2015), and the Ghanaian market is purely controlled by consumers as a societal market (Agyenim-Boateng, Benson-Armer, \& Russo, 2015).

The study into consumer decision making have received extensive attention from various researches. According to Bray (2008), consumer decision making is examined over 300 years. Based on this, researches have attempted to investigate consumers' in Ghana their decision making towards buying made in Ghana brand. In a study, Quartey and Abor (2011) examined that Ghanaians prefer more locally made textiles due to its affordability to that of foreign products. Another study, Abeasi (1998) indicated that majority of consumers' select foreign product to local brands, and a related study, Frimpong (2013) claimed that consumers prefer foreign brand whilst they have low interest in patronising local products and services. Similarly, study, Frimpong (2011) discovered that consumers prefer foreign product than domestic products. Also, Opoku and Akorli (2009) shows that consumers consider country of origin product more important than price, as well as other attributes in the product. Additionally, Bamfo (2012) revealed that element of ethnocentrism affect consumer selection of made 
in Ghana product, and similar study by Richard (2016) found that religion and traditional factors largely influenced consumers' patronage of made in Ghana product. Further to this, Agyekum, Haifeng, and Agyeiwaa (2015) discovered that age, income level, as well as educational aspect affect buying decision making of consumer towards local brand. More so, Mensah, Bahhouth, and Ziemnowicz (2011) found that life style, culture, tradition influence consumer purchase decision on locally produced products. Quansah, Okoe, and Angenu (2015) found a relationship of consumer perception and beliefs towards buying decision making. Kissiedu (2012) examined that majority of consumers prefer foreign products.

Clearly, these past studies outlined have demonstrated little attention into the factors that influences the choice of brands made in Ghana. Nonetheless, there is extensive study into the consumer behaviour theories in relation to motivation need theory, theory of planned behaviour, and theory of reasoned action. Conversely, consumer decision making towards made in Ghana brand with respect to perceived risk have not received clear publication in any related field of consumer behaviour, marketing, economics, in the Ghanaian context. Based on this, the study is particularly positioned to advance knowledge in the theories of buyer behaviour pertaining to the purchase consumer decision model (also known as EKB model - Engel, Kollet, Blackwell) by contributing to the empirical findings. Significantly, product producers, entrepreneurs, marketing professional, retail operators as well as other related stakeholders will broaden their understanding in consumer buying.

\subsection{Research Questions}

The following research questions were formulated to guide the study:

- What is significant influence of the performance risk on brand made in Ghana consumer decision making towards non-perishable products category?

- What is significant influence of the financial risk on brand made in Ghana consumer decision making towards non-perishable products category?

- What is significant influence of the physical risk on brand made in Ghana consumer decision making towards non-perishable products category?

- What is significant influence of the social risk on brand made in Ghana consumer decision making towards non-perishable products category?

The next section dealt with reviewed of the literature in relation to theories of consumer behaviour with more emphasis on consumer decision model, definitions, empirical perspectives and perceived risk factors explained. This is followed by methodology, next is results findings, and final part discuss results findings and previous findings.

\section{Literature Review}

\subsection{Theoretical and Empirical Aspect of Consumer Decision Making}

The study of consumer behaviour theory in relation to decision making model has widely been studied. Among these studies can be traced or linked to consumer economics, rural sociology, social and mathematical psychology, social anthropology, political science, consumer behaviour, marketing, advertising, as well as selling and sales management (Kassarjian, 1971).

Accordingly, Bray (2008); Dudovskiy (2013) outlined a number of consumer behaviour theories, which include: (i) theory of reasoned action, where the core of the theory posits that consumers act on a behaviour with respect to consumer's intention to create particular outcome, (ii) motivation-need theory, implies that consumers make buying decision in order to fulfill their needs, such as physiological, safety, love, esteem and self-actualisation, (iii) theory of planned behaviour, emphasis consumers ability to demonstrate skills, resources, as well as other prerequisites needed to act upon given behaviour, and (iv) consumer decision model is highly influenced by an interaction between processed stimuli inputs, environment, as well as individual factors. Also, the model evolved around various stages of buying decision process, namely, need recognition, search of information (associated with consumer exposure, attention, comprehension, acceptance and retention), evaluation of alternatives, purchase, post-puchase reflection, and divestment. Similarly, Kassarjian (1982) asserted that consumer behaviour also associated with grand elegant theories, which consist of classical utility theory, psychoanalytic theory, learning theory and field theory, and in a related study by Lautiainen (2015) established that consumer behaviour consist of four factors; (i) cultural, (ii) social, (iii) personal, and (iv) psychological factors.

Nguyen and Gizaw (2014) claimed that consumers are exposed to different window of information and range of products. Mostert (2006) categorised consumer behaviour into two: (i) personal consumers, where purchase product and services for personal / household use, and (ii) organisational consumers, where purchase products 
and services to run an organisation. Also, Jaakkola (2007) reported that professional consumer services represents a unique setting for purchase decision-making, and cannot be considered equivalent to the organisational or consumer setting. Another study by Lautiainen (2015) identified four types of decision making based on the degree of consumer involvement; (i) complex buying behaviour, where the consumer is highly involved due to the expensive nature of product, risky and reflects the consumer itself, (ii) dissonance, where the consumers are highly involved, because the product can be expensive, (iii) habitual decision - making choices usually based on routine with little conscious effort, and (iv) variety seeking buying behaviour, where consumers are interested to change the brand for the sake of variety rather than dissatisfaction.

In a research, Tanksale, Neelam, and Venkarachalam (2014), defined consumer decision making as mental orientation couple with choice of product. In other studies, (Domie, 2013; Zeng 2013; Cimino, 2015), consumer decision making refers to ways in which individuals, groups, and organisations select, buy, use, and dispose of goods, ideas to satisfy their needs and desires. Also to Mostert (2006), consumer decision making implies every thought, motive, sensation towards daily exchanges. Kumar and Joseph (2014), defined consumer decision making as the pre-purchase behaviour, which is preceded by the intention to buy or consume. Quansah et al. (2015), consumer decision making is the physical activity and decision process individuals engage in evaluating, acquiring, disposing of products and services. Solomon (1996), consumer buying behaviour means the integral process of decision-making and also activity of engaging in selecting, purchasing, consuming and disposing products. Darko (2012) stated that consumer decision making is a degree of which individuals make decisions to spend their available resources. Among related study, Nyarko, Asimah, and Agbemava (2015) established that consumer decision making serves as need arousal with respect to the emotional and psychological needs relevant to the individual consumer.

Domie (2013) found that product country of origin is more important among consumer consumption. Nguyen and Gizaw (2014) found price-quality influences consumer intention of buying. Also, Dudovskiy (2015) revealed the relationship between habits and previous experience of consumer buying decision. In another study, Tanksale et al. (2014) shows that recreational, brand conscious, novelty-fashion conscious, perfectionist-high quality conscious, habitual brand-loyal consumer affect buying decision. More so, Karimi (2013) indicated that webstore affect consumer intentions of product selection. Other study, Hamilton (2009) revealed significant association of poverty narrative and household decision making. Yoon and Carpenter (2013) examined the effect of aging and consumer decision making, and a study by Hall et al. (1995) claimed that high and low involvement products are associated with gender, family structure in relation to family decision making. Maguire and Zhang (2016); Richard and Masud (2016) identified that cultural intermediaries personal, consuming preferences and practices are significant to buying decision making. Narsey and Russell (2011) reported that varying degrees of self-reflexive consciousness impact on consumer consumption. Amankwah (2016) indicated that multiples of factors affect buying decision making, such as brand name, price, trust, advertising, loyalty and brand satisfaction, and a related study by Adofo (2014) examined that package of a beauty product influence consumer consumption. Darko (2012) noted that sales promotional activity significantly influence buying behvaiour. Nyarko et al. (2015) shows that celebrity endorsements pose highly attractive and influential. Most importantly, celebrity endorsement affect consumer purchase intentions. Bajde and Ottlewski (2016) discovered that social-economic factors affect consumer logical decision exchanges. Quansah et al. (2015) shows that consumer behaviour focuses on the rate individuals make decisions to spend their resources on consumption related products (time and money).

\subsection{Perceived Risk Factors Influence on Consumer Decision Making}

The need for a consumer to make buying decision towards any product of their choice seem simple but very complex in nature. This is due to the fact that a lot of internal and external stimulus affect or impact on consumer choice. It is not surprising that many researchers have attempted to uncover factors which affect consumer buying behaviour. This study introduced perceived risk factors by positioning in the theory of consumer decision model in the case of brands made in Ghana. Perceived risk is a psychological construct, also quantifiable and inherent in consumer product evaluations and decisions (Lim, 2002; Kozup, 2017). The study delved into perceived risk factors and the extent to which it can engender decision making of consumers towards made in Ghana products.

\subsubsection{Performance Risk}

This type of risk is applied to the consumers' risk perceptions of product performance. It is important to state that performance risk typically related to performance characteristics of product attributes (Ha, 2002; Yu, Lee, \& Damhorst, 2012). Another study stated that performance risk (functional risk) concern the buyer's mind sat that 
the product being considered for purchase will not work efficiently (Schiffman, O'Cass, Paladino, \& Carlson, 2013; Monash University, 2017). In addition, other study reported that performance risk consist of the possibility of item failing to meet the performance requirement originally intended (Dai, Forsy, \& Kwon, 2014), and in a similar study the possibility that the purchased products failed to meet consumers' expectations (Lim, 2002). Further to this, performance risk happens when the product selected does not perform as desired and thus not deliver the benefits sought or expected by consumers (Ha, 2002).

$H_{1}$ : There is significant influence of the performance risk on brand made in Ghana consumer decision making towards non-perishable products category.

\subsubsection{Financial Risk}

This type of risk is explained as the possibility of monetary loss based on the consumer selection of a product (Lim, 2002; Schiffman et al., 2013), and in a related study, financial risk consist of the consumer likelihood of suffering a monetary loss from a product purchase decision (Dai et al., 2014). Additionally, financial risk is noted as a net financial loss to a customer, including the possibility that the product may need to be repaired, replaced or the purchase price refunded (Ha, 2002). Another study revealed that consumers are afraid that a purchase might strip them of their income sources at that time or in the future (Lake, 2017).

$\mathrm{H}_{2}$ : There is significant influence of the financial risk on brand made in Ghana consumer decision making towards non-perishable products category.

\subsubsection{Physical Risk}

This type of risk is much concern with the buyer's mind towards the product being considered for purchase either will be harmful, unhealthy or cause injury (Schiffman et al., 2013; Monash University, 2017). Also, physical risk refers to the degree that products are harmful to buyers' health (Lim, 2002), and in a similar study, Lake (2017) reported that physical risk consist of an item that could cause bodily harm to a buyer. Hiruyawipada and Paswan (2006) stated that physical risk enhance consumers' propensity to select unique information about new products. More so, physical risk is noted as a product which does not meet consumer requirement (Glassman, 2017).

$H_{3}$ : There is significant influence of the physical risk on brand made in Ghana consumer decision making towards non-perishable products category.

\subsubsection{Social Risk}

Schiffman et al. (2013), states that consumer inability to select rightful product result in social dissatisfaction. Also, Lake (2017) discussed that social risk occurs where a consumer buying decision making is mainly related to their social status. Similarly, Lim (2002) asserted that consumers become much concerned about the purchase decision regarding other consumers. This has resulted the possibility that consumers' shopping behaviour is not accepted by other society members.

$H_{4:}$ There is significant influence of the social risk on brand made in Ghana consumer decision making towards non-perishable products category.

\section{Methodology}

The study was conducted at the Sunyani Technical University campus in Sunyani Municipality. The population for the study consist of part-time students, as well as staff of the University. The categories of this population were selected due to the fact that they have a high tendency to spend more resources (time and money) towards purchases, and being considered as affluent in the Ghanaian consumer societal settings. The non-probability sampling method with respect to convenience sampling method was used to select participants for the study (Burns \& Bush, 2014). Overall, the study determined a sample size of 225 which are male and female. A structured questionnaire survey instrument was used to collect data from the participants or respondents for the study (Malhotra \& Birks, 2003). Out of 225 questionnaire survey distributed, a total of 206 were retrieved. The distribution and collection of the survey instrument were carried out by researchers of the study. Also, distribution and collection of data were done during day time between hours of $8 \mathrm{am}-5 \mathrm{pm}$ (Saturdays' and Sundays' only). The study lasted for 6 weekend days (Burns and Bush, 2014).

The questionnaire survey instrument used in the study consist of three sub-divided sections in obtaining data of respondents. These parts are categorised as A, B \& C, which part A consist of demographic characteristics including age, gender, marital status and education level. Part B consist of consumer involvement of brand made in Ghana with the focus on the consumer level of buying brand made in Ghana, most purchased product made in Ghana, consumer level of awareness about the product made in Ghana, location where consumers buy products, 
and brand made in Ghana buying decision makers. The part A and B of the designed questionnaire instrument was adopted from Hendriana (2013); Burns \& Bush (2014). Additionally, the final part of the instrument that is $\mathrm{C}$ was structured in the five point likert measurement rating scale. This means the rating scale of $1-5$, where $1=$ strongly disagree, $2=$ disagree, 3 neutral, $4=$ agree, and 5 strongly agree. Notably, this part of the structured questionnaire survey related to the research questions; perceived risk influence on brand made in Ghana decision making towards non-perishable and non-food product category. Among the key variables investigated includes performance risk, financial risk, physical risk, and social risk. This part of the questionnaire was adopted from Sabir et al. (2013). The questionnaire survey was pre-tested, refined and finally administered. The questionnaire survey retrieved rate was $92 \%$.

Pertaining to the data analysis and evaluation procedure, the data was computed and analysed with the used of Statistical Package for Social Sciences (SPSS) version 25. Also, the study conducted reliability of the data collection instrument by the use of Statistical Package for Social Sciences. The reliability value of Cronbach's Alpha was 0.633 . The study employed basic frequency assessment for demographic characteristics. This section is included in the study in order to ascertain range of purchasing decision pattern towards brand made in Ghana, as well as their level of involvement. Accordingly, the study evaluated the research questions by the use of linear regression to establish significant influence of the independent variable (IDV) on dependent variable (DV).

\section{Results and Discussion}

\subsection{Demographic Characteristics}

Table 1 depicts the demographic characteristics of the respondents for the study. On the whole, the analysis displayed gender, age, marital status and qualification level of respondents. The total number of respondents comprises 206, regarding gender, 117 respondents $(56.8 \%)$ were males whilst 89 respondents $(43.2 \%)$ were females. This shows that there were more males than females. Pertaining to the age of respondents, most of the respondents were between 25-31 years (97\%), this is followed by those between 32-38 years (24.3\%), also between 39-45 years represent (13.6\%), next between 18-24 years constitute (10.2\%), few were between 45-52 years $(4.4 \%)$, and $53+$ years $(0.5 \%)$ considerably. With respect to the marital status, 110 respondents $(53.4 \%)$ consist of those that were single whereas about 96 respondents (46.6\%) were married. Lastly, qualification of respondents, 92 respondents $(44.7 \%)$ consist of higher national diploma, 71 respondents $(34.5 \%)$ those with a first degree, 25 respondents $(12.1 \%)$ those with diploma, 12 respondents $(5.8 \%)$ constitutes second degree, 3 respondents $(1.5 \%)$ those with $\mathrm{PhD} / \mathrm{DBA}$, and 3 respondents $(1.5 \%)$ those with professional certificates respectively.

Table 1. Demographic characteristics

\begin{tabular}{llcc}
\hline Variable & Category & Frequency & Percentage \\
\hline Gender & Male & 117 & 56.8 \\
& Female & 89 & 43.2 \\
Age & $18-24$ & 21 & 10.2 \\
& $25-31$ & 97 & 47.1 \\
& $32-38$ & 50 & 24.3 \\
& $39-45$ & 28 & 13.6 \\
& $46-52$ & 9 & 4.4 \\
Marital Status & Single & 1 & .5 \\
& Married & 110 & 53.4 \\
& Diploma & 25 & 46.6 \\
& HND & 92 & 12.1 \\
& First Degree & 71 & 44.7 \\
& Second Degree & 12 & 34.5 \\
& PhD / DBA & 3 & 5.8 \\
& Professional & 3 & 1.5 \\
& & & 1.5 \\
\hline
\end{tabular}

\subsection{Analysis of Consumer Involvement of Brand Made in Ghana}

Table 2 depicts the consumer involvement of brands made in Ghana. Regarding the consumer level of involvement in terms of buying made in Ghana brands, 109 (52.9\%) constitute respondents who had average 
involvement, 64 respondents (31.1\%) were found to have high involvement, 23 respondents $(11.2 \%)$ were found to have low involvement and also, 10 respondents (4.9\%) represent those who had very high involvement. With respect to, made in Ghana brands purchased, 93 respondents (45.1\%) were found to have purchased weaving / wax print, 57 respondents $(27.7 \%)$ constitute those that purchased detergent, followed by 28 respondents $(13.6 \%)$ found to have purchased footwear, next 20 respondents $(9.7 \%)$ constitute those that purchased raw rice, and 8 respondents $(3.9 \%)$ were found to have purchased electrical appliances. Pertaining to consumers level of awareness of made in Ghana brands, 84 respondents (40.8\%) represent those with average awareness of brands made in Ghana, 71 respondents (34.5\%) were found those with high awareness of brands made in Ghana, 30 respondents (14.6\%) consist of those with very high those awareness of brands made in Ghana, and finally 21 respondents $(10.2 \%)$ represent those that have low awareness of brands made in Ghana. In addition, location of where consumers purchase brands made in Ghana, 142 respondents $(68.9 \%)$ buy from open market where consumer make purchases, 33 respondents $(16.0 \%)$ buy from super markets, 13 respondents $(6.3 \%)$ buy from boutique shops, 11 respondents $(5.3 \%)$ buy from door-to-door salespersons, and lastly, 7 respondents $(3.4 \%)$ buy from shopping malls consumer make purchase decision. In the usage of the brands made in Ghana, 134 respondents $(65.0 \%)$ represent personal use, those that used brand made in Ghana, 63 respondents (30.6\%) buy for family use, and 9 respondents $(4.4 \%)$ buy for friends.

Table 2. Consumer involvement of brand made in Ghana

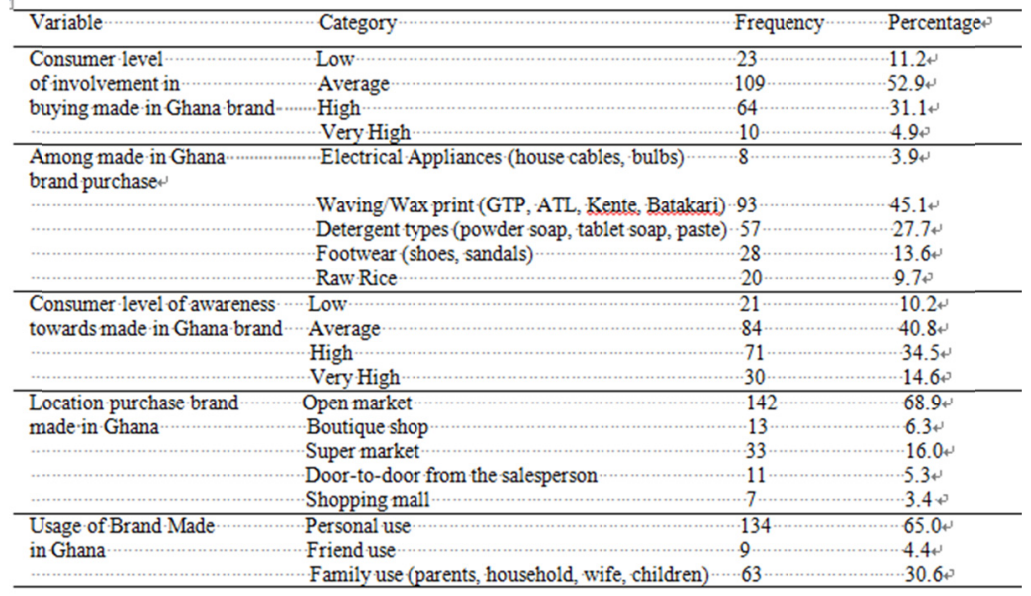

\subsection{Analysis on Hypotheses for Linear Regression Results}

The study shows the results obtained on the basis of linear regression to find the significant influence of the independent variable on dependent variable towards non-perishable products category.

Table 3 the coefficient results shows that it is significant $(t=2.648$, p-value $0.001<0.05)$. Hence there is a significant influence of the performance risk on brand made in Ghana consumer decision making towards non-perishable products category.

Table 3. Linear regression results of the performance risk on brand made in Ghana consumer decision making towards non-perishable products category

\begin{tabular}{|c|c|c|c|c|c|}
\hline \multirow[t]{2}{*}{ Model } & \multicolumn{2}{|c|}{ Unstandardized Coefficients } & \multirow{2}{*}{$\begin{array}{l}\text { Standardized Coefficients } \\
\text { Beta }\end{array}$} & \multirow[t]{2}{*}{$\mathrm{t}$} & \multirow[t]{2}{*}{ Sig. } \\
\hline & $\mathrm{B}$ & Std. Error & & & \\
\hline 1 (Constant) & 2.648 & .118 & & 22.482 & .000 \\
\hline Performance Risk & -.111 & .034 & -.225 & -3.296 & .001 \\
\hline
\end{tabular}

a. Dependent Variable: Consumer buying made in Ghana brand

Table 4 the coefficient results indicates that it is not significant $(t=2.449$, $p$-value $0.173>0.05)$. Hence there is no significant influence of the financial risk on brand made in Ghana consumer decision making towards non-perishable products category. 
Table 4. Regression results of the financial risk on brand made in Ghana consumer decision making towards non-perishable products category

\begin{tabular}{|c|c|c|c|c|c|}
\hline \multirow[t]{2}{*}{ Model } & \multicolumn{2}{|c|}{ Unstandardized Coefficients } & \multirow{2}{*}{$\begin{array}{l}\text { Standardized Coefficients } \\
\text { Beta }\end{array}$} & \multirow[t]{2}{*}{$\mathrm{t}$} & \multirow[t]{2}{*}{ Sig. } \\
\hline & $\mathrm{B}$ & Std. Error & & & \\
\hline 1 (Constant) & 2.449 & .123 & & 19.948 & .000 \\
\hline Financial Risk & -.049 & .036 & -.095 & -1.367 & .173 \\
\hline
\end{tabular}

a. Dependent Variable: Consumer buying made in Ghana brand

Table 5 the coefficient results indicates that it is not significant $(\mathrm{t}=2.285$, $\mathrm{p}$-value $0.932>0.05)$. Hence there is no significant influence of the physical risk on brand made in Ghana consumer decision making towards non-perishable products category.

Table 5. Regression results of the physical risk on brand made in Ghana consumer decision making towards non-perishable products category

\begin{tabular}{|c|c|c|c|c|c|}
\hline \multirow[t]{2}{*}{ Model } & \multicolumn{2}{|c|}{ Unstandardized Coefficients } & \multirow{2}{*}{$\begin{array}{l}\text { Standardized Coefficients } \\
\text { Beta }\end{array}$} & \multirow[t]{2}{*}{$\mathrm{t}$} & \multirow[t]{2}{*}{ Sig. } \\
\hline & $\mathrm{B}$ & Std. Error & & & \\
\hline 1 (Constant) & 2.285 & .136 & & 16.839 & .000 \\
\hline Physical Risk & .003 & .039 & .006 & .085 & .932 \\
\hline
\end{tabular}

a. Dependent Variable: Consumer buying made in Ghana brand

Table 6 the coefficient results indicates that it is not significant $(\mathrm{t}=2.332$, $\mathrm{p}$-value $0.671>0.05)$. Hence there is no significant influence of the social risk on brand made in Ghana consumer decision making towards non-perishable products category.

Table 6. Regression results of the social risk on brand made in Ghana consumer decision making towards non-perishable products category

\begin{tabular}{|c|c|c|c|c|c|}
\hline \multirow[t]{2}{*}{ Model } & \multicolumn{2}{|c|}{ Unstandardized Coefficients } & \multirow{2}{*}{$\begin{array}{l}\text { Standardized Coefficients } \\
\text { Beta }\end{array}$} & \multirow[t]{2}{*}{$\mathrm{t}$} & \multirow[t]{2}{*}{ Sig. } \\
\hline & $\mathrm{B}$ & Std. Error & & & \\
\hline 1 (Constant) & 2.332 & .098 & & 23.690 & .000 \\
\hline Social Risk & -.015 & .036 & -.030 & -.425 & .671 \\
\hline
\end{tabular}

a. Dependent Variable: Consumer buying made in Ghana brand

On the whole, the perceived risk variables with the t-value and p-value shows that, only the performance risk is found significant influence on brand made in Ghana consumer decision making towards non-perishable products category $(\mathrm{t}=2.571, \mathrm{p}$-value $0.001<0.05)$. Among the variables that are rejected with no significant influence on brand made in Ghana includes financial risk $(\mathrm{t}=2.449, \mathrm{p}$-value $0.173>0.05)$, physical risk $(\mathrm{t}=2.285$, $\mathrm{p}$-value $0.932>0.05)$, and social risk $(\mathrm{t}=2.332$, $\mathrm{p}$-value $0.671>0.05)$.

\section{Discussion of Findings}

Table 1 findings ascertain respondents characteristics which also indicates their involvement in buying non-perishable made in Ghana brands category. The study confirmed that men and women in a Ghana are among the buying decision makers of brands made in Ghana. Also, other categories under the demographic characteristics such as age, marital status, as well as education level affirmed the caliber of respondents that were involved in the study (Hall et al., 1995; Opoku \& Akorli, 2009; Agyekum et al., 2015). With respect to Table 2, findings support the view that consumers in Ghana are much aware about the attitudinal change campaign to select brands made in their home territory (Abissath, 2015). In addition, the study confirmed that Ghanaians prefer more locally made textiles and wax (Quartey \& Abor, 2011). Aside this, the study support the view that there is much low interest and desire for many other brands made in Ghana to foreign products (Abeasi, 1998; Opoku \& Akorli, 2009; Kissiedu, 2012; Frimpong, 2013). Further to this, the study support the view that consumers are exposed to different window of information, as well as range of products (Nguyen \& Gizaw, 2014). More so, the finding of the study confirmed that consumers make purchase decision for personal, household and for use by others (Mostert, 2006), and highly involved in the buying process (Lautianen, 2015). 
The overall hypotheses analysis (Table 3, 4, 5 and 6) centers on perceived risk influence on brand made in Ghana towards non-perishable products category. Among the findings, performance risk support the view that consumers buying decision making largely influenced by risk associated with functionality of product (Hong-Youl, 2002; Lim, 2002; Yu et al., 2012; Schiffman, O'Cass, Paladino, \& Carlson, 2013; Dai, Forsy, \& Kwon, 2014; Monash University, 2017). Analysis of financial risk does not support the view that consumers buying decision has been based on their resources (Hong-Youl, 2002; Lim, 2002; Quansah et al., 2015; Schiffman et al., 2013; Lake, 2017). Also, physical risk does not support the view that buyer's consider this factor in the choice of brand made in Ghana (Lim, 2002; Hiruyawipada \& Paswan, 2006; Schiffman et al., 2013; Monash University, 2017), and lastly, social risk has been rejected on the basis that it does not influence consumer buying decision making.

\section{Conclusion}

The study explored perceived risk influence on brand made in Ghana consumer decision making towards non-perishable products category. Linear regression model was used to ascertain the significant influence of perceived risk on brand made in Ghana consumer decision making towards non-perishable products category. The study found that perceived risk has significant influence on brand made in Ghana consumer decision making. In other related findings, financial risk has no significant influence on brand made in Ghana consumer decision making. Also, physical risk has no significant influence on brand made in Ghana consumer decision making. Further analysis shows that social risk has no significant influence on brand made in Ghana consumer decision making.

\section{References}

Abeasi, K. (1998). Private Enterprise Foundation: Survey on Patronage of Made-In-Ghana Goods.

Abissath, M. K. (2015). Why Ghanaians Should Patronise Made-In-Ghana Goods and Services: Government of Ghana.

Adofo, A. O. (2014). The effect of beauty product packaging on consumer buying decision (A case of selected shops in the New Juabeng Municipality, Ghana). The Business \& Management Review, 5(3), 14.

Agyekum, C. K., Haifeng, H., \& Agyeiwaa, A. (2015). Consumer Perception of Product Quality. Microeconomics and Macroeconomics, 3(2), 25-29. https://doi.org/10.5923/J.m2conomics.20150302.01

Agyenim-Boateng, Y., Benson-Armer, R., \& Russo, B. (2015). Winning in Africa's consumer market.

Amankwah, M. O. (2017). Determinants of Purchase Decisions of Consumers of the Products of Nestle Ghana Ltd.

Bajde, D., \& Ottlewski, L. (2016). Cultural Challenges of Social-Economic Innovation: The Case of Housing for Help. Consumer Culture Theory, 18, 93-107.

Bamfo, B. A. (2012). Consumer attitude toward products made in Ghana. Global Journal of Business Research, $6(1)$.

Bray, J. P. (2008). Consumer Behaviour Theory: Approaches and Models.

Burns, A. C., \& Bush, R. F. (2014). Marketing Research (7th ed.). Pearson Education Limited, England.

Cimino, J. (2015). Observing Consumer Behaviour: Past, Present, and Future.

Dai, B., Forsythe, S., \& Kwon, W. S. (2014). The impact of online shopping experience on risk perceptions and online purchase intentions: does product category matter? Journal of Electronic Commerce Research, 15(1), 13.

Darko, E. (2012). The Influence of Sales Promotion on Consumer Buying Behaviour in the Telecom Industry: The Case of Vodafone Ghana.

Domie, S. P. (2013). Assessing The Factors Influencing Consumer Switch From Local To Imported Products: A case study of Kasapreko Company Limited-Ghana.

Dudovskiy, J. (2013). Consumer Decision Making Process: A detailed analysis.

Dudovskiy, J. (2015). A Brief Literature Review on Consumer Buying Behaviour.

Frimpong, C. Y. (2013). Addressing the Consumer Preference for Foreign Goods.

Frimpong, S. K. (2011). A Comparison of Effect between Domestic versus Foreign Brands on Consumer Purchasing Decision in Ghana. In Proceedings of the 8th International Conference on Innovation \& 
Management.

Glassman, M. (2017). How To Counter Your Customers Perceived Risk. Selling Power Magazine.

Ha, H. Y. (2002). The effects of consumer risk perception on pre-purchase information in online auctions: Brand, word-of-mouth, and customized information. Journal of Computer-Mediated Communication, 8(1). https://doi.org/10.1111/j.1083-6101.2002.tb00160.x

Hall, J. Shaw, M., Johnson, M., \& Oppenheim, P. (1995). Influence of Children on Family Consumer Decision Making. European Advances in Consumer Research, 2, 45-53.

Hamilton, K. (2009). Consumer decision making in low-income families: The case of conflict avoidance. Journal of Consumer Behaviour, 8(5), 252-267. https://doi.org/10.1002/cb.285

Hendriana, E., Mayasari, A. P., \& Gunadi, W. (2013). Why do college students buy counterfeit movies? International Journal of E-Education, E-Business, E-Management and E-Learning, 3(1), 62. https://doi.org/10.7763/ijeeee.2013.v3.194

Hirunyawipada, T., \& Paswan, A. K. (2006). Consumer innovativeness and perceived risk: implications for high technology product adoption. Journal of Consumer Marketing, 23(4), 182-198. https://doi.org/10.1108/07363760610674310

Jaakkola, E. (2007). Purchase Decision-Making within Professional Consumer Services Organisational or Consumer Buying Behaviour? Journal of Marketing Theory, 7(1). https://doi.org/10.1177/1470593107073847

Karimi, S. (2013). A Purchase Decision Making Process Model of Online Consumers and Its Influential Factor.

Kassarjian, H. H. (1971). Personality and Consumer Behaviour: A Review. Journal of Marketing Review, 8(4), 409-418.

Kassarjian, H. H. (1982). The Development of Consumer Behaviour Theory. Association for Consumer Research, (20-22).

Kissiedu, K. O. (2012). Consumers'Attitude towards Foreign and Domestic Chocolates.

Kozup, J. (2017). Risk of Consumer Product.

Kumar, N. A., \& Joseph, J. (2014). A Study on consumer behavior towards FMCG products among the rural-suburban Hhs of Ernakulam. Journal of Global Economics, 1-10. https://doi.org/104172/2375-4389.1000127

Lake, L. (2017). Learn About Perceived Risk and How to Overcome it.

Lautiainen, T. (2015). Factors affecting consumers' buying decision in the selection of a coffee brand.

Lim, N. (2002). Classification of Consumers' Perceived Risk: Sources versus Consequences. In Proceedings of the Sixth Pacific Conference on Information Systems, Tokyo, Japan, 540-554).

Maguire, J. S., \& Zhang, D. (2016). Shifting the Focus from Consumers to Cultural Intermediaries: An Example from the Emerging Chinese Fine Wine Market. Consumer Culture Theory, 18(1-27). https://doi.org/10.1108/S0885-211120160000018001

Malhotra, K. \& Birks, F. (2003) Marketing Research, Pearson Education Limited: Harlow.

Mensah, E. C., Bahhouth, V., \& Ziemnowicz, C. (2011). Ethnocentrism and purchase decisions among Ghanaian consumers. The Journal of Applied Business and Economics, 12(4), 20.

Milner, T. (2013). A review of consumer decision-making models and development of a new model for financial services, Journal of Financial Services Marketing, 18(2).

Monash University (2017). Performance Risk.

Mostert, P. G. (2006). Buying behaviour of South African internet users.

Narsey, V., \& Russell, C. A. (2011). Realistically fake: Self-reflexive consciousness, ironic (dis) engagement with hybrid reality television, and their impact on consumption. Research in Consumer Behavior, 13, 233-247.

Nguyen, T. H. \& Gizaw, A. (2014). Factors that Influence Consumer Purchasing Decision of Private Label Food Product: A case study of ICA Basic.

Nyarko, I. K., Asiamah, V., Agbemava, F., \& Tsetse, E. K. 2015, the influence of celebrity endorsement on the 
buying behaviour of the Ghanaian Youth: A study of Fan Milk Ghana Advertising. International Journal of Business and Management Review, 3(11), 1-16.

Opoku, R. A., \& Akorli, P. A. (2009). The preference gap: Ghanaian consumers' attitudes toward local and imported products. African Journal of Business Management, 3(8), 350.

Quansah, F., Okoe, A., \& Angenu, B. (2015). Factors Affecting Ghanaian Consumers' Purchasing Decision of Bottled Water. International Journal of Marketing Studies, 7(5), 76. https://doi.org/105539/ijms.v7n5p76

Quartey, P., \& Abor, J. (2011). Do Ghanaians prefer imported textiles to locally manufactured ones? Modern Economy, 2(01), 54. https://doi.org/104236/me.2011.21009.

Richard, A., \& Masud, I. (2016). Factors Influencing Consumer Choice in Hotel Selection in Ghana. International Journal of Economics, Commerce and Management, 4(11).

Sabir, R. I., Ahmad, W., \& Razzaq, A. S. (2013). Factors Affecting Consumers Complicity Towards Counterfeit Mobile Phones in Pakistan. Middle-East Journal of Scientific Research, 18(1), 68-74. https://doi.org/10.5829/idosi.mejsr.2013.18.1.11666

Schiffman, L., O'Cass, A., Paladino, A., \& Carlson, J. (2013). Consumer behaviour. Pearson Higher Education AU.

Solomon, M. R. (2004). Consumer behaviour: Buying, Having, and Being. Business \& Economics.

Tanksale, D., Neellam, N. \& Ventatachalam, R. (2014). Consumer decision making styles of young adult consumer in India. Science Direct, 211-218.

Yoon, C. \& Carpenter, S. M. (2013). Aging and consumer decision making, Ann N Y \& Academy Science, 235(1), 12. https://doi.org/10.1111/j.1749-6632.2011.06390.x

Yu, U. J., Lee, H. H., \& Damhorst, M. L. (2012). Exploring multidimensions of product performance risk in the online apparel shopping context: Visual, tactile, and trial risks. Clothing and Textiles Research Journal, 30(4), 251-266.

Zeng, R. (2013). Attributes influencing home buyers' purchase decisions: a quantitative study of the Wuhan residential housing market.

\section{Copyrights}

Copyright for this article is retained by the author(s), with first publication rights granted to the journal.

This is an open-access article distributed under the terms and conditions of the Creative Commons Attribution license (http://creativecommons.org/licenses/by/4.0/). 